\title{
DINAMIKA PEMBELAJARAN TATAP MUKA TERBATAS DI KALANGAN MAHASISWA
}

\section{Fifit Fitriansyah $^{1^{*}}$}

${ }^{1}$ Universitas Bina Sarana Informatika, Jakarta, Indonesia

*Corresponding Author: ( fifit.ffy@bsi.ac.id

\section{Info Artikel}

Sejarah Artikel:

Diterima: $14 / 12 / 2021$

Direvisi : 27/12/2021

Disetujui:30/12/2021

\section{Keywords:}

Limited Face-to-face

Learning, Covid-19

pandemic, Students

Kata Kunci:

Pembelajaran tatap muka terbatas, Pandemi Covid-

19, Mahasiswa

\begin{abstract}
The COVID-19 pandemic has changed the way learning was originally done offline, is now done online. As a result, various uses of learning media are applied to each educator, one of which is learning videos. The purpose of this study was to see the implementation of limited face-to-face learning carried out by students and to see the implementation problems of students' choices in limited face-to-face learning. The research method used is descriptive qualitative analysis. The results of this study show that there are differences in choices where in the first class $80 \%$ choose face-to-face learning, while in the second class as much as $71 \%$ choose Non-PTM. This shows that the implementation of face-to-face learning is still a polemic among students.
\end{abstract}

Abstrak. Pandemi COVID-19 telah merubah cara belajar yang sedianya dilakukan secara offline, kini dilakukan secara online. Akibatnya berbagai penggunaan media pembelajaran diterapkan pada masing-masing pendidik salah satunya video pembelajaran. Tujuan penelitian ini adalah guna melihat pelaksanaan pembelajaran tatap muka terbatas yang dijalankan oleh mahasiswa serta melihat problematika penyelenggaraan atas pilihan mahasiswa dalam pembelajaran tatap muka terbatas. Metode penelitian yang digunakan adalah analisis deskriptif kualitatif. Hasil penelitian ini terdapat perbedaan pilihan di mana pada kelas pertama sebanyak $80 \%$ memilih pembelajaran tatap muka, sementara pada kelas kedua sebanyak $71 \%$ memilih Non-PTM. Ini menunjukan bahwa pemberlakuan pembelajaran tatap muka masih menjadi polemik di kalangan mahasiswa.

How to Cite: Fitriansyah, F. (2022). DINAMIKA PEMBELAJARAN TATAP MUKA TERBATAS DI KALANGAN MAHASISWA. Prima Magistra: Jurnal Ilmiah Kependidikan, 3(1), 123-130. https://doi.org/10.37478/jpm.v3i1.1438

Alamat korespondensi:

Universitas Bina Sarana Informatika. Jln. Kramat Raya No. 98, Senin, Jakarta Pusat

@ fifit.ffy@bsi.ac.id

\section{Penerbit:}

Program Studi PGSD Universitas Flores.

@ primagistrauniflor@gmail.com 


\section{PENDAHULUAN}

Pandemi Covid-19 telah memaksa masyarakat dunia dalam melaksanakan tatanan hidup hingga pola pembelajaran yang selama ini dilakukan secara tatap muka kini dilaksanakan secara online (Ningsih, 2020; Gunawan \& Amaludin, 2021). Perubahan ini yang pada gilirannya merubah kebiasaan masyarakat yang jika selama ini setiap orang dipaksa hidup dalam situasi serba cepat, namun dengan kondisi saat ini semua berjalan lambat dan serba terbatas, tidak terkecuali pada ranah pembelajaran.

Pembelajaran yang terbiasa dilakukan secara tatap muka, seketika berubah menjadi online atau dalam jaringan (daring) tentu saja hal ini berdampak pada perubahan strategi pembelajaran, media pembelajaran yang digunakan hingga evaluasi pembelajaran. Transformasi model pembelajaran tatap muka ke model pembelajaran jarak jauh secara daring berdampak pada pengalaman belajar mahasiswa (Fredy et al., 2020).

Pembelajaran sendiri merupakan proses interaksi peserta didik dengan pendidik dan sumber belajar pada satu lingkungan belajar. Konteks interaksi dalam proses pembelajaran adalah interaksi sosial, yaitu hubungan antara individu dengan kelompok, dalam hal ini guru selaku individu berinteraksi dengan sekelompok peserta didik (Chalil \& Latuconsina, 2008).

Pembelajaran juga merupakan suatu proses yang dilakukan oleh individu untuk memperoleh suatu perubahan perilaku yang baru secara keseluruhan, sebagai hasil dari pengalaman individu itu sendiri dalam interaksi dengan lingkungannya. Dengan kata lain, pembelajaran dapat dikatakan sebagai usaha memperoleh perubahan perilaku dalam diri individu yang diperoleh dari proses interaksi dengan lingkungannya (Tim Pengembang Ilmu Pendidikan FIP-UPI, 2007).

Jika melihat esensi pembelajaran berdasarkan definisi di atas, dapat diartikan bahwa adanya interaksi antara pendidik, peserta didik dan sumber belajar menjadi hal yang perlu dirancang sedemikian rupa sesuai dengan tujuan pembelajaran sehingga terciptanya proses pembelajaran yang efektif dan efisien.

Namun sejak diumumkannya Maret 2020, di mana Indonesia termasuk negara yang berdampak Covid-19, maka mulai diberlakukannya pembelajaran secara daring baik pada jenjang SD, SMP, SMA hingga jenjang Pendidikan Tinggi (Aulia \& Dwi, 2021; Lubis et al., 2021; Maharani \& Exacta, 2020). Hampir 2 tahun pandemi Covid-19 melanda, dan seiring dengan perubahan dan percepatan pemerintah dalam penanganan kasus Covid-19 di Indonesia, kini perlahan mulai diberlakukan kehidupan 'new normal' dengan kondisi tetap menjaga protokol kesehatan.

Belum lagi penyesuaian dengan kondisi 'new normal' yang dijalankan masyarakat, kini polemik adanya kebijakan pembelajaran tatap muka di tengah pandemi Covid-19 yang dilaksanakan mulai Juli 2021 masih terus menuai pro dan kontra. Bahkan ada kesalahpahaman yang berkembang di masyarakat, seolah-olah pemerintah akan membuka sekolah seperti halnya di saat normal.

Direktur Jenderal PAUD, Pendidikan Dasar dan Pendidikan Menengah, Kemendikbudristek, Jumari, S.T.P., M.Si menegaskan, yang akan dilaksanakan pada Juli nanti adalah pembelajaran tatap muka (PTM) secara terbatas (Kasih, 2022). Alihalih pemerintah telah menyelesaikan vaksinasi terhadap pendidik dan tenaga pendidikan maka pembelajaran tatap muka terbatas ini dapat dilangsungkan.

Jika melihat kepada proses pembelajaran sendiri merupakan aktivitas yang paling utama. Sebab, keberhasilan pencapaian tujuan pembelajaran bergantung pada bagaimana proses pembelajaran berlangsung secara efektif (Fitriansyah, 2020). Untuk itu, tentu saja pembelajaran harus dirancang sesuai dengan tujuan pembelajaran.

Pembelajaran Tatap Muka (PTM) terbatas sendiri adalah berupa kebijakan yang dilaksakan pada satuan pendidikan yang tertuang dalam SKB Empat Menteri tentang Panduan Penyelenggaraan Pembelajaran di 
Masa Pandemi Covid-19 yang akan dilaksanakan melalui 2 (dua) fase yaitu masa transisi dan masa kebiasaan baru. PTM pada masa transisi akan berlangsung selama 2 (dua) bulan sejak dimulainya PTM di satuan pendidikan. Setelah masa transisi selesai maka PTM memasuki masa kebiasaan baru.

Pada prosesnya, tentu saja pelaksaan PTM tidak mudah. Akan banyak bermunculan masalah-masalah yang dihadapi, salah satunya adalah tidak tersedianya sarana dan prasarana yang mendukung layanan kesehatan, keselamatan warga satuan pendidikan, pengaturan fasilitas tempat belajar, pengaturan jumlah peserta didik, dan durasi waktu setiap mata pelajaran per hari. Satuan Pendidikan dapat menyiapkan beberapa alternatif PTM, yang pada akhirnya akan terpilih satu bentuk PTM yang sesuai dengan kondisi lingkungan sekolah dan tetap menerapkan protokol kesehatan.

Namun demikian, tidak semudah yang dibayangkkan, dalam pelaksaan PTM dinamika dan polemik di masyarakat bermunculan, terutama pada siswa dan orang tua. Ini merupakan masalah baru yang timbul, di mana kebiasaan yang selama ini dijalankan secara online, dan kini beralih kepada offline membuat siswa dan orang tua perlu penyesuaian kembali.

$\begin{array}{ccc}\text { Berdasarkan } & \text { Peraturan } & \text { Menteri } \\ \text { Pendidikan dan } & \text { Kebudayaan } & \text { bahwa }\end{array}$ perencanaan pembelajaran tatap muka perlu memperhatikan beberapa hal diantaranya: 1) Melakukan vaksinasi kepada seluruh pendidik dan tenaga kependidikan; 2) Meningkatkan imun peserta didik, pendidik dan tenaga kependidikan; 3) Mempersiapkan sarana dan prasarana yang sesuai protokol kesehatan. Namun demikian, sebelum diterapkannya pelaksanaan pembelajaran tatap muka terbatas, Kemdikbud telah mensosialisasikan dan menerbitkan buku panduan pembelajaran masa pandemik (Kemendikbud, 2020).

Dalam pelaksanaan pembelajaran tatap muka terbatas ini juga perlu menerapkan prinsip kehati-hatian karena berkaitan dengan kesehatan dan keselamatan warga di sekolah, sehingga penggunaan protokol kesehatan wajib diterapkan secara ketat sesuai dengan aturan pelaksanaan tatap muka terbatas. Pembelajaran tatap muka terbatas merupakan pembatasan jumlah peserta didik dalam satu kelas, sehingga perlu mengatur jumlah dengan sistem rotasi dan kapasitas 50\% dari jumlah siswa pada normalnya, persetujuan orang tua siswa, penerapan protokol kesehatan yang ketat, tenaga kependidikan telah melakukan vaksinasi, hingga sarana dan prasaran pendukung pelaksanaan protokol kesehatan tersedia dan memadai (Onde et al., 2021).

Di kalangan mahasiswa sendiri, adanya pelaksanaan Pembelajaran Tatap Muka (PTM) Terbatas ini menjadi masalah baru yang dihadapi sebab hal ini dinilai mendadak dan butuh penyesuaian sebelum terlaksananya PTM terbatas ini. Di Universitas Bina Sarana Informatika sendiri, kebijakan penyelenggaraan PTM terbatas ini dilakukan berdasarkan edaran Kemenristekdikti tentang diperbolehkannya melaksanakan PTM terbatas dengan melalui prosedur yang ketat dan pendaftaran kesediaan melaksanakan PTM bagi mahasiswa yang mau dan mendaftar.

Namun demikian, tidak jarang masih banyak mahasiswa yang enggan melaksanakan PTM terbatas ini. Oleh karena itu, tujuan penelitian ini adalah untuk melihat bagaimana dinamika dan fenomena pelaksanaan PTM Pada level pendidikan tinggi (di kalangan mahasiswa) sehingga mendapatkan gambaran mengenai proses pelaksanaan PTM yang ada.

\section{METODE PENELITIAN}

Penelitian ini dilakukan di Universitas Bina Sarana Informatika pada Mahasiswa Program Studi Ilmu Komunikasi dengan melakukan proses pengambilan data dengan beberapa cara yaitu: 1) Studi pustaka di lakukan dengan cara membaca dan mencatat berbagai referensi seperti buku, jurnal, majalah, artikel, internet dan lain-lain yang berkaitan dengan penelitian yang sedang di lakukan; 2) Observasi yang dilakukan dengan cara mengumpulkan data dengan mengadakan pengamatan langsung terhadap objek penelitian melalui lembar observasi terkait pelakasanaan PTM, dan dengan memberikan 
lembar survey kepada 30 orang mengenai kesiapan mahasiswa dalam mengikuti PTM Terbatas serta; 3) Wawancara kepada dosen dan beberapa mahasiswa terkait pengambilan data lebih mendalam dan komprehensif.

Pada penelitian ini, menggunakan metode deskriptif kualitatif yakni berupa katakata berdasarkan gambaran yang terjadi di lapangan secara mendalam dan apa adanya (Fitriansyah, 2019). Adapun proses analisis data penelitian kualitatif (Rijali, 2018) sebagai sebagaimana gambaran berikut:

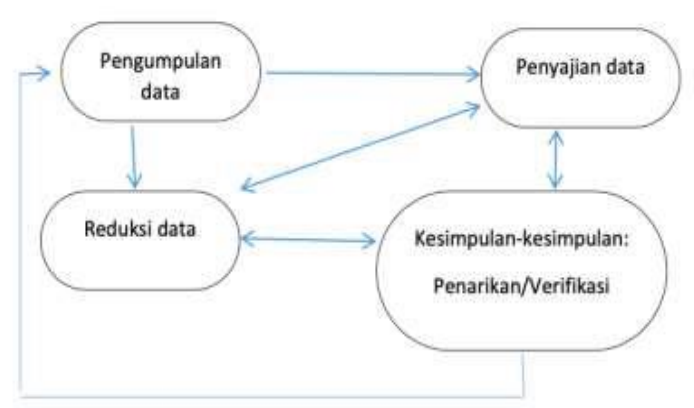

Gambar 1 Proses Analisis Data Penelitian Kualitatif

Dalam menganalisis data, peneliti melakukan berdasarkan data yang diperoleh dari catatan lapangam observasi dan wawancara dengan menghasilkan transkip yang kemudian diolah menjadi data yang dideskripsikan dengan apa adanya berdasarkan hasil temuan data di lapangan.

\section{HASIL DAN PEMBAHASAN}

\section{Prosedur Pelaksanaan PKM Terbatas bagi Mahasiswa}

Berdasarkan Peraturan Menteri Pendidikan dan Kebudayaan bahwa perencanaan pembelajaran tatap muka perlu memperhatikan beberapa hal diantaranya: 1) Melakukan vaksinasi kepada seluruh pendidik dan tenaga kependidikan; 2) Meningkatkan imun peserta didik, pendidik dan tenaga kependidikan; 3) Mempersiapkan sarana dan prasarana yang sesuai protokol kesehatan. Namun demikian, sebelum diterapkannya pelaksanaan pembelajaran tatap muka terbatas, Kemdikbud telah mensosialisasikan dan menerbitkan buku panduan pembelajaran masa pandemik (Kemendikbud, 2020).

Prosedur yang harus dijalankan oleh mahasiwa yang mengikuti PTM adalah dengan terlebih dahulu: 1) PTM terbatas di Universitas
BSI akan dilaksanakan mulai Semester Gasal 2021/2022 pada pertemuan ke 9 (sembilan) yang jatuh pada hari Senin tanggal 08 November 2021; 2) Dosen dan mahasiswa yang dapat mengikuti PTM adalah yang sudah mendapatkan vaksinasi tahap 1 (satu); 3) Mahasiswa memberikan konfirmasi kesediaan atau penolakan mengikuti PTM melalui http://students.bsi.ac.id 4) Memperhatikan Protokol Kesehatan Pencegahan Covid 19 tentang pengaturan jumlah mahasiswa yang dapat menuju kampus maka PTM tidak berlaku disemua matakuliah; Mahasiswa yang berhak mengikuti PTM adalah semua mahasiswa aktif pada Semester Gasal 2021/2022. Biro Administrasi Akademik (BAAK) akan membagi tiap kelas ke dalam 2 kelompok yaitu kelompok A dan B berdasarkan nomor urut. Jumlah maksimal mahasiswa per kelompok adalah $50 \%$ dari jumlah mahasiswa per kelas; 5) Pada awal pelaksanaan PTM di Semester Gasal 2021/2022, kelompok A mempunyai 4 kali kesempatan PTM sebelum Ujian Akhir Semester yaitu pada pertemuan 9,11,13, dan 15, sedangkan kelompok B mempunyai 3 kali kesempatan yaitu pada pertemuan 10,12, dan 14; 6) Jadwal perkuliahan masing-masing kelompok dapat diakses pada laman www.bsi.ac.id mulai tanggal 01 November 2021. Presensi kehadiran mengajar dan kuliah tetap dilakukan melalui aplikasi MyBest; 7) Dalam hal mahasiswa akan melakukan penyesuaian metode perkuliahannya dari metode daring ke luring atau sebaliknya, maka mahasiswa harus mengirimkan pemberitahuan ke BAAK melalui alamat email; 8) Pemberitahuan lebih lanjut tentang mekanisme PTM disampaikan berdasarkan kebijakan Pemerintah dan Surat Keputusan Rektor tentang Protokol Pencegahan Corona Virus 19 (UBSI, 2021).

Dengan adanya prosedur pelaksanaan PTM Terbatas yang dijalankan oleh mahasiswa maka dilakukan hal-hal teknik terkait pelaksanaannya, sebagaimana gambaran 1) Mahasiswa telah memastikan diri untuk mengikuti perkuliahan dalam kondisi sehat; 2) Mencuci tangan setibanya di kampus; 3) Melakukan check in pada aplikasi peduli lindungi yang terdapat di area kampus; 4) Dosen akan melakukan check suhu tubuh sebelum mahasiswa masuk ke dalam ruang kelas; 5) Menggunakan masker selama melakukan 
perkuliahan; 6) Selama perkuliahan berlangsung mahasiswa tetap menjaga jarak duduk antar teman dan tidak berkerumun.

\section{Dinamika Pelaksanaan PTM Terbatas Pada Mahasiswa}

Pelaksaan penelitian PTM (Pembelajaran Tatap Muka) terbatas ini dilakukan pada mahasiswa dalam 2 kelas yang berbeda antara kelas yang mayoritas menginginkan PTM dengan kelas dengan mayoritas menginginkan tetap belajar secara online.

Pada hasil pada kelas pertama yang diperoleh dari survey pengisian data mahasiswa yang mengajukan pelaksanaan PTM dari 30 orang mahasiswa hanya 6 orang yang menginginkan PTM terbatas, sementara 24 orang lainnya tetap menginginkan pembelajaran dilakukan secara online, sebagaimana terdapat dalam gambar di bawah ini:

JUMLAH PEMILIH PTM TERBATAS MAHASISWA PADA KELAS PERTAMA

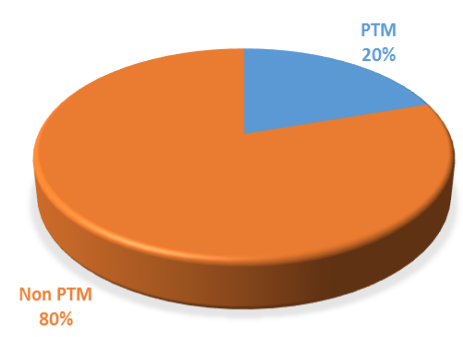

Gambar 2. Hasil Pilihan mahasiswa terhadap PTM Pada Kelas Pertama (Sumber: Dokumentasi Pribadi)

Jika melihat kepada hasil gambar di atas bahwa sebanyak 20\% mahasiswa memilih PTM dan $80 \%$ memilih non-PTM atau tetap belajar secara online. Berdasarkan hasil wawancara dengan sejumlah mahasiswa di dapati bahwa mahasiswa yang tidak menginginkan PTM memiliki alasan: 1) mahasiswa berada di luar kota (kampung halaman) sehingga tidak dapat dengan segera kembali ke kampus; 2) mahasiswa telah terikat kontrak pekerjaan dengan perusahaan dan telah menyepakati adanya shift dalam bekerja sehingga tidak diperkenankan berubah-ubah shift secara mendadak; 3) masih adanyanya mahasiswa yang belum melakukan vaksin karena khawatir dan memiliki penyakit bawaan (Fitriansyah, 2021).

Sementara berdasarkan hasil voting dengan kelas kedua yang menyetujui pelaksaan
PTM terbatas ini sejumlah 15 orang dari jumlah total mahasiswa 21 orang dengan 6 orang memilih tetap belajar secara online, sebagaimana terdapat dalam gambar di bawah ini:

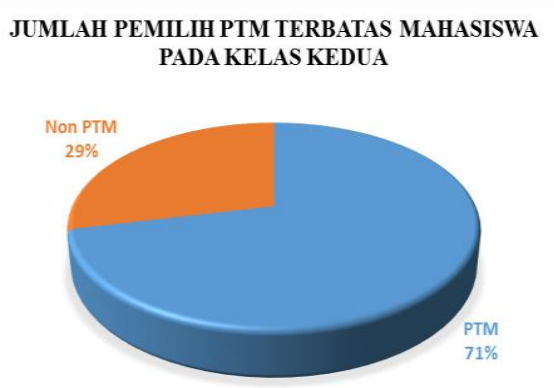

Gambar 3. Hasil Pilihan mahasiswa terhadap PTM Pada Kelas Kedua (Sumber: Dokumentasi Pribadi).

Melihat kepada hasil di atas, tergambar bahwa pada kelas kedua jumlah mahasiswa yang memilih PTM sebanyak $71 \%$ sementara mahasiswa dengan pilihan tetap belajar secara online (Non-PTM) sebanyak 29\%. Berdasarkan hasil wawancara atas pilihan tersebut mahasiswa yang lebih banyak memilih PTM dengan alasan: 1) tidak memiliki kesibukan lain selain kuliah;2) Jenuh dan bosan dengan aktifitas keseharian di rumah saja; 3) membutuhkan pertemuan secara langsung dengan dosen terkait mata kuliah karya; 4) agar mendapatkan uang saku dari orang tua. Berdasarkan alasan-alasan ini lah mengapa lebih banyak mahasiswa yang memilih untuk melaksanakan pembelajaran secara PTM di bandingkan dengan pembelajaran secara online.

Pembelajaran Tatap Muka (PTM) Terbatas yang dilaksanakan di Universitas Bina Sarana Informatika ini dilakukan dengan cara setiap mahasiswa yang datang untuk melaksanakan PTM anak dilakukan pengecekan suhu tubuh terlebih dahulu sebelum masuk ke dalam ruang kelas. Selanjutnya mahasiswa menempati tempat duduk masing-masing dengan jarak duduk kurang lebih 1 meter antar mahasiswa. Kapasitas ruang kelas maksimal 20 mahasiswa, dan selama pembelajaran berlangsung mahasiswa dan dosen diwajibkan untuk menggunakan masker. Usai pembelajaran selesai, maka mahasiswa diwajibkan meninggalkan ruang kelas tanpa melakukan aktifitas lain seperti berkumpul dan lain sebagainya.

Proses pembelajaran dilakukan secara 
online dan offline, di mana bagi mahasiswa yang tidak memilih melaksanakan PTM maka tetap harus mengikuti perkuliahan secara daring melalui laman mybest.bsi.ac.id. Dosen pun tetap harus memantau aktifitas mahasiswa secara daring melalui laman LMS tersebut, Whats App grup atau melakukan pembelajaran via Zoom meeting. Adanya dua kegiatan pembelajaran sekaligus dalam satu waktu bukanlah hal yang mudah, di mana dosen dituntut untuk aktif secara tatap muka dan online kepada mahasiswa, inilah yang pada gilirannya menciptakan polemik baru bagi dosen pengampu mata kuliah.

\section{Problematika PTM Bagi Orang Tua}

Pada tingkat pendidikan tinggi sendiri penyelenggaraan PTM mungkin tidak terlalu berdampak pada orang tua. Hal ini mengingat, anak yang sudah dewasa telah dapat menentukan sendiri cara belajarnya sesuai dengan aturan yang ada di masing-masing kampus. Namun demikian, tidak jarang masih ada orang tua yang mengkhawatirkan anak mereka untuk dapat melaksanaan PTM ini terlebih bagi mereka yang tinggal di luar Jabodetabek (di kampung halaman) adanya kasus lonjakan Covid-19 menjadi kekhawatiran tersendiri.

Untuk itu, dalam pelaksanaan pembelajaran tatap muka terbatas ini perlu menerapkan prinsip kehati-hatian karena berkaitan dengan kesehatan dan keselamatan warga di sekolah, sehingga penggunaan protokol kesehatan wajib diterapkan secara ketat sesuai dengan aturan pelaksanaan tatap muka terbatas. Pembelajaran tatap muka terbatas merupakan pembatasan jumlah peserta didik dalam satu kelas, sehingga perlu mengatur jumlah dengan sistem rotasi dan kapasitas $50 \%$ dari jumlah siswa pada normalnya, persetujuan orang tua siswa, penerapan protokol kesehatan yang ketat, tenaga kependidikan telah melakukan vaksinasi, hingga sarana dan prasaran pendukung pelaksanaan protokol kesehatan tersedia dan memadai (Onde et al., 2021).

Namun demikian adanya proses PTM terbatas tidak lantas menjawab masalah pembelajaran, hal ini didapati pada saat PTM berlangsung mayoritas mahasiswa memiliki kesulitan dalam menerima materi pembelajaran secara langsung. Hal ini mengingat selama mahasiswa melakukan pembelajaran secara online sehingga sudah terbiasa komunikasi satu arah, tidak aktif untuk berdiskusi dan bertanya serta kesibukan dan gangguan lainnya saat di rumah. Inilah yang mengakibatkan mahasiswa yang hadir di kelas menjadi pasif, konsentrasi menurun serta respon terhadap pemberian materi ajar yang kurang (Fitriansyah, 2021).

Dinamika ini tidak hanya menjadi polemik baru di kalangan mahasiswa, namun sebelumnya pada tingkat satuan pendidikan sekolah telah terlebih dahulu menjalankan Pembelajaran Tatap Muka (PTM) Terbatas. Bahkan beberapa kekhawatiran orang tua disebabkan karena: 1) Tingkat kepatuhan masyarakat terhadap protokol kesehatan masih sangat rendah di mana sebanyak $80 \%$ yang lebih patuh menerapkan protokol kesehatan adalah individu berusia diatas 60 tahun. Sementara anak-anak usia sekolah dan orang dewasa masih sering lalai dalam penerapan protokol kesehatan seperti menggunakan masker, dan mencuci tangan (Simanjuntak et al., 2020); 2) Sosialisasi bahaya Covid-19 di nilai masih kurang optimal sehingga banyak masyarakat masih meremehkannya; 3) Masih bias nya kejelasan prosedur yang dijalankan pada pembelajaran tatap muka terbatas (Powa et al., 2021).

Problematika PTM terbatas ini tentu saja memerlukan perhatian lebih baik dari Pemerintah, Guru, Siswa bahkan orang tua. Sebab, tidak hanya menjadi permasalahan baru, di kalangan siswa tetapi juga menjadi kekhawatiran baru bagi orang tua terkait penyebaran virus Covid-19 yang semakin masif terutama bagi orang tua yang tinggal jauh dari anaknya (di luar Jabodetabek), atau orang tua dengan kondisi manula dan disertai penyakit penyerta. Inilah yang pada gilirannya menjadi dilema tersendiri. Untuk itu, dalam menjawab kekhawatiran tersebut, pihak kampus dan dosen harus memastikan kegiatan pembelajaran yang berjalan sesuai dengan protokol kesehatan yang ada tanpa mengurangi kekhidmatan proses pembelajaran

\section{SIMPULAN DAN SARAN}

Proses pembelajaran pada gilirannya merupakan proses penerimaan ilmu yang berlangsung secara sengaja antara peserta didik dan pendidik dengan melibatkan unsurunsur pembelajaran seperti kurikulum, media, metode, bahan ajar hingga evaluasi pembelajaran. Untuk itu guna tercapainya 
proses pembelajaran yang efektif perlu dipersiapkan dengan matang. Di tengah kondisi pandemi Covid-19 ini tentu saja bukan hal yang mudah dalam melaksanakan pembelajaran, terlebih pemberlakuan PTM terbatas menjadi adaptasi baru dalam pembelajaran, butuh keterlibatan aktif dan peran serta stake holder dalam memfasilitasi hal tersebut, sehingga baik siswa maupun orang tua akan merasa aman dan nyaman dalam mengikuti proses pembelajaran. Dalam pelaksanaan PTM Terbatas pada Universitas Bina Sarana Informatika ini, terdapat perbedaan pilihan di mana pada kelas pertama sebanyak 80\% memilih PTM, sementara pada kelas kedua sebanyak $71 \%$ memilih Non-PTM. Ini menunjukan bahwa pemberlakuan PTM masih menjadi polemik di kalangan mahasiswa.

\section{DAFTAR PUSTAKA}

Aulia, N., \& Dwi, D. F. (2021). Efektivitas Pembelajaran Daring Di Masa Pandemi Covid-19 Pada Jenjang Sekolah Dasar Di SD Negeri 105334 Penara Kebun Tanjung Morawa Dengan Pemanfaatan Portal Rumah Belajar KEMDIKBUD. Education

Achievement: Journal of Science and Research, 36-46. https://pusdikrapublishing.com/index.php/jsr/article/vie w/335

Chalil, A., \& Latuconsina, H. (2008). Pembelajaran Berbasis Fitrah (1st ed.). Jakarta: Balai Pustaka. Google Scholar

Fitriansyah, F. (2019). Analisis Kebutuhan Pengembangan Pembelajaran Penulisan Naskah PR I. Cakrawala-Jurnal Humaniora, 19(1), 79-86. https://ejournal.bsi.ac.id/ejurnal/index.p hp/cakrawala/article/view/5046

Fitriansyah, F. (2020). USING ANNOUNCING LEARNING VIDEOS IN IMPROVING STUDENT LEARNING OUTCOME. Jurnal Dikdas, 8(1), 87-93. Google Scholar

Fitriansyah, F. (2021). DEVELOPMENT OF LEARNING VIDEOS AS INDEPENDENT LEARNING RESOURCES DURING THE COVID19 PANDEMIC. Jurnal Pendidikan dan Kebudayaan Missio, 13(2), 101110. https://doi.org/10.36928/jpkm.v13i2.83 4

Fredy, F., Prihandoko, L. A., \& Anggawirya, A. M. (2020). The Effect of Learning Experience on the Information Literacy of Students in the Ri-Png Border During Covid-19 Period. International Journal of Multicultural and Multireligious Understanding, 7(10), 171-180.

http://dx.doi.org/10.18415/ijmmu.v7i10 .2067

Gunawan, Y. I. P., \& Amaludin, A. (2021). Pemanfaatan Teknologi Pembelajaran Dalam Jaringan di Masa Pandemi Covid-19. Madaniyah, 11(2), 133-150. https://journal.stitpemalang.ac.id/index. php/madaniyah/article/view/195

Kemendikbud. (2020). Panduan Penyelenggaraan Pembelajaran Di Masa Pandemi COVID-19. Retrieved from

https://www.kemdikbud.go.id/Main/Blo g/2020/06/Buku-Saku-Panduan-

Pembelajaran-Di-\%0AMasa-PandemiCovid19.

Lubis, H., Ramadhani, A., \& Rasyid, M. (2021). Stres akademik mahasiswa dalam melaksanakan kuliah daring selama masa pandemi Covid 19. Jurnal Psikologi, 10(1), 31-39. http://dx.doi.org/10.30872/psikostudia. v10i1.5454

Maharani, A., \& Exacta, A. P. (2020). Analisis Kesulitan Belajar Pada Mata Pelajaran Matematika Dengan Pembelajaran Dalam Jaringan (Daring) Selama Masa Darurat Covid-19 Pada Siswa Kelas VIII SMP Negeri 2 Ngadirojo Tahun Ajaran 2019/2020. Jurnal Pendidikan, Sains Sosial, dan Agama, 6(2), 6-12. https://doi.org/10.53565/pssa.v6i2.182

Ningsih, S. (2020). Persepsi Mahasiswa Terhadap Pembelajaran Daring Pada Masa Pandemi Covid-19. JINOTEP (Jurnal Inovasi Dan Teknologi Pembelajaran): Kajian Dan Riset 
Dalam Teknologi Pembelajaran,7(2), 124-132.

http://dx.doi.org/10.17977/um031v7i 22020p124

Onde, M. K. L. O., Aswat, H., Sari, E. R., \& Meliza, N. (2021). Analisis Pelaksanaan Pembelajaran Tatap Muka Terbatas (TMT) di masa New Normal terhadap Hasil Belajar Matematika di Sekolah Dasar. EDUKATIF: JURNAL ILMU PENDIDIKAN, 3(6), 4400-4406. https://www.edukatif.org/index.php/edu katif/article/view/1449

Powa, N. W., Tambunan, W., \& Limbong, M. (2021). ANALISIS PERSETUJUAN ORANG TUA TERHADAP RENCANA PEMBELAJARAN TATAP MUKA TERBATAS DI SMK SANTA MARIA JAKARTA. Jurnal Manajemen Pendidikan, 10(2), 100111. https://doi.org/10.33541/jmp.v10i2.327 4

Rijali, A. (2019). Analisis data kualitatif. Alhadharah: Jurnal Ilmu Dakwah, 17(33), 81-95. http://dx.doi.org/10.18592/alhadharah. v17i33.2374

Simanjuntak, D. R., Napitupulu, T. M., Wele, A. M., \& Yanie, R. (2020). GAMBARAN KEPATUHAN MASYARAKAT MENERAPKAN PROTOKOL KESEHATAN COVID19 DI TEMPAT UMUM PERIODE SEPTEMBER 2020 DI DKI JAKARTA.

http://repository.uki.ac.id/id/eprint/3191

Tim Pengembang Ilmu Pendidikan FIP-UPI. (2007). Ilmu dan Aplikasi Pedidikan, Bagian 1 Ilmu Pendidikan Teoretis. In Handbook (2nd ed.). Bandung: PT IMPERIAL BHAKTI UTAMA. Google Scholar

UBSI. (2021) Mekanisme Perkuliahan Tatap Muka (PTM) Pada Semester Gasal 2021/2022 (2021). Jakarta: USBI

Kasih, A.P. (2022). Kemendikbud: Semua Sekolah Wajib Tatap Muka, Pemda Tak Boleh Larang. kompas.com 